\title{
Integrating the 6 Cs of the 21st Century Education into the English Lesson and the School Literacy Movement in Secondary Schools
}

\section{Mirjam Anugerahwati}

Universitas Negeri Malang

\section{Abstract}

In the face of the 21st Century education, the concept of the $6 \mathrm{Cs}$ is becoming more and more popular among educators. Schools now are striving to educate their students to achieve the competences of thinking critically and solving real-world problems, conducting clear communication, having collaborative practices, respecting culture, developing creativity, and making good use of connectivity. But what do they mean? This paper proposes some ways the $6 \mathrm{Cs}$ can, and should, be integrated in the

Corresponding Author: Mirjam Anugerahwati mirjam.anugerahwati.fs@um.ac.id

Received: 23 January 2019

Accepted: 26 February 2019

Published: 17 March 2019

Publishing services provided by Knowledge E

(c) Mirjam Anugerahwati. This article is distributed under the terms of the Creative Commons Attribution License, which permits unrestricted use and redistribution provided that the original author and source are credited.

Selection and Peer-review under the responsibility of the International Seminar on Language, Education, and Culture Conference Committee. English lessons, particularly in secondary schools. The suggestions refer to ways of integrating the $6 \mathrm{Cs}$ in relation with the Strengthening of Character Education currently being implemented in secondary schools, in line with the nine priorities of the President.

Keywords: 21st century education, the $6 \mathrm{Cs}$, English lesson

\section{Background}

In this era, education in all levels should be considerably different from what was usually conducted in the previous era. Not only are conditions different, but demands in the real world are also far different from what we, as teachers, are used to having. We are now living in the 21st century, and life for our students is full of innovations and challenges that we did not even imagine could exist. Students, from kindergarten to high schools, are surrounded by technology and amenities in their daily lives, and they do most of their activities using technology. Some say that those conditions pose new problems and challenges for the students, for which education should prepare them. The term 21st century education was then created which encompasses the aspects that should be integrated with the day to day lessons in all subject matters. Formerly, the aspects cover the $4 \mathrm{Cs}$ : Communication, Critical thinking, Collaboration, and Creativity. However,education experts then came up with additional Cs: Miller (2015) coined 2 
other Cs: Connectivity and Citizenship, while Fullan (2015), prefers the term Character education and Culture, respectively.

Quite a number of studies have been conducted concerning the implementation of the 4 Cs (Hidi and Harackiewicz. 2000; Lombardi, 2007; Maphosa and Mashau, 2014; Alismail and McGuire, 2015, and Fatimah and Santiana 2017, to name but a few); however, no guidelines have been provided concerning the implementation of the $6 \mathrm{Cs}$ especially in the teaching of English as a foreign language. This paper, then, aims to explain some ways that the $6 \mathrm{Cs}$ can, and should be, integrated in the English lessons, particularly in Junior High School.

\section{The 6Cs in the 21st Century Education}

Eighteen years into the 21st century, many things have happened that have changed the way we see and do things, including in the field of education. Researchers and education experts have outlined the Cs about the education in the 21st Century, and they cover: critical thinking, collaboration, communication, creativity, citizenship/ culture, and character education/connectivity. What does each C mean, however? Miller (2015) and Fullan (2015) assert that the first C, critical thinking, refers to the ways that students filter, analyze, and question any information that they might find in various media, be it written, spoken, or broadcast, and then synthesize it to fit their understanding.

Collaboration points to the way students use various personalities, talents, and knowledge to work together and produce something new. The third C, communication, refers to the ability to put forward ideas and information in a clear, meaningful way. Communication has four main purposes, which are to "inform, instruct, motivate, and persuade" audience. (Miller, 2015). The information presented should be clear, concise, correct, and coherent, so that readers/listeners will get the intended meaning.

The next $\mathrm{C}$, which stands for Creativity, refers to the ability of students to make use of their knowledge and/or talents to create something new, or to produce something in a new way. The next 2 Cs are new coinages by two education experts, Miller and Fullan. Miller created the fifth $C$ as embracing culture, and the sixth is utilizing connectivity; while Fullan chose the word citizenship and character education, respectively. But what do those two "new" Cs encompass?

Embracing culture, or, in the words of Fullan, citizenship, involves the ability of students to be in touch with everything that surrounds them, to know and appreciate where they come from, and the values and beliefs that people in their society hold, and their history as a society. 
The last $\mathrm{C}$, connectivity or character education, both refer to the skill that we as teachers should foster in our students. As part of a global world where technology is part of everyday life, students should be able to connect with their friends and other people around them in building a better world, and in the process, teachers should foster in them the eagerness to become "responsible, caring, and contributing" citizens.

In line with the skills that 21st century education should foster in students, in Indonesia there is a very similar issue decreed int he Presidential decree, which is called "Nawa Cita', a word originating from the Sanskrit language which means the Nine Priorities. President Joko Widodo, of the Republic of Indonesia, declared in 2017 that the building of the Indonesian nation should cover the nine priorities, the eighth of which concerns the overhauling the character of the nation. The biggest emphasis of this priority is the building of the character of the citizens, so much so that it is also decreed that in primary and secondary education, $70 \%$ of the curriculum should focus on the character education for the students. (https://walizahid.com)

How, then, can this issue be integrated into the English subject, as one of the compulsory subjects in Junior and Senior High School? The subsection below will discuss that matter.

\section{Integrating the 21st Century Skills into the English Lessons}

English, as one of the compulsory subjects in Junior and Senior High schools, is often considered as a difficult subject for students. Limited vocabulary and unfamiliar grammar rules are two of the most cited sources of the difficulty; and as a result, teachers often feel pessimistic in integrating character values into the subject. One of the most frequent comments I hear from teachers is "How can I build students' character, Ma'am, when they don't even understand the words in the text?" Of course, this is the area of another discussion, but I would like to point out that students can be made to enjoy the English subject, and even reach good achievements, when they feel that they are doing something meaningful with the language, eventhough it is not easy.

As stated in the 2013 Curriculum, English subject covers various genres/text types, which are transactional, interpersonal, and functional texts (which are further classified into specific/short functional and functional texts). All those text types can be taught by integrating the $6 \mathrm{Cs}$. Following is the proposed activities that can be carried out in the English lesson. 


\section{Interpersonal Text}

Critical thinking can be fostered during the teaching of interpersonal text, for instance in "apologizing" (Basic Competences 3.1 and 4.1, grade 7). In the conversation, three people are talking.

Ali: Friends, I'm so sorry for coming late; we had a sudden visit from my uncle and aunt in Surabaya

Brenda: That's OK, Ali, we haven't started anyway

Charles: Fine, Ali, but you did remember to bring your laptop, right?

In this interpersonal text, Ali is apologizing for coming late, but his friends are not angry. When you want to build students' critical thinking skills, you can ask questions such as "What is the situation in this conversation?" please explain your answer; or, "What do you think they will be doing, and why did Charles ask about laptop?" In this conversation, we aim to let students use the potentials of their critical thinking; the conversation itself is quite short, but we can ask the students to infer some important things about the contents. From the vocabulary side, there's no unfamiliar words that can make thw conversation difficult to understand.

In the second C, collaboration, students can be asked to work in small groups or in pairs. They can be asked to answer the questions above concerning the short conversation. In the group work students must use as much English as possible as the teacher walks around the classroom. For the next $\mathrm{C}$, Communication, students read the answer to the questions and/or perform the conversation in front of the class.

The next $C$ is Creativity; here the students can be asked to create a conversation of apology, with the provided conversation as a basis. In groups they can be asked to create the beginning of the comversation, or the end of it, or both beginning and ending. An alternative would be for the students to make a different conversation of apology with the situation provided by the teacher. Here the teacher can remind them of the structure of conversation (greetings and closing) which are not present in the model conversation.

The fifth $C$, that is culture or citizenhip, trains the students to be aware of their surroundings, of where they come from. In the same situation of interpersonal text of apology, they can be asked to compare the expressions of apology in Bahasa Indonesia and English, find the similarities and differences. Besides involving the issue of culture, this is also a higher order thinking (HOT) task, which is very much encouraged in the present curriculum. 
Lastly, connectivity or character education, encourages students to connect with other people and build a strong, noble character. Still in the same context, students can be asked to apply their knowledge of the expressions of apology and in groups make a conversation relating to a real situation where something happens which makes it necessary for the students to apologize to a friend, or to someone older. In this case, the task involves the building of responsibility and caring in the students.

\subsection{Functional text}

Still another example of the implementation of the $6 \mathrm{Cs}$ in English lesson in school is as follows. In year 9, students should work with narrative, in particular fairy tales (Basic Competences 3.7 and 4.7). Let us take a fairy tale by Oscar Wilde, entitled the Selfish Giant. Not many students may have read this story, but this is a really beautiful story which can be extensively exploited to implement the 6Cs. Of course, the lesson should first deal with the unfamiliar words in the story, such as trespassers, prosecuted, etc.

In implementing critical thinking, students can be asked to read the story and then discuss some questions given by the teacher; some examples of the questions would be:

1. why is the giant called selfish?;

2. If you were him, would you do the same thing (build a high wall and put up a notice board fobidding people/kids toplay in his garden)? Explain your answer.

In discussing these questions, the second $\mathrm{C}$ (collaboration) is also being practiced.

In implementing the third C, Communication, students can be asked either to present the results of their group discussion orally or write them in an essay and submit them to the teacher. The important thing to be emphasized would be that their report should be concise and clear. In the next C, creativity, the teacher can ask students, still in groups, to create a different ending to the story, one that they feel is better or more interesting than the original one.

The fifth C, Culture or citizenship, involves the activity that can engage the students to explore what they know about private properties, or about the habits of children playing in gardens. They can be asked to talk about the customs in their surroundings, whether people also consider some things as private properties, and what they do about them. They can be asked to share their opinion about practices such as putting fence around the properties, and so on. 
In implementing the last $\mathrm{C}$, connectivity or character education, the teacher can make use of many issues in the fairy tale to arouse students' views of the moral lessons in the story. For instance, the teacher can talk about the giant; is he a lonely giant? Is he really selfish? What makes him have a personality like that? What do the students think about his change of personality? Is he happy after he lets the children play in his garden? Who does he miss? Who is the little boy, actually? What do you think the little boy simbolizes? Certainly, the students should discuss the moral lesson in the story and explain why they think so. Many more questions can be asked which relate to character education from this story; the important thing is that the discussions should guide students to become caring and contributing citizens.

\section{Conclusions}

In the 21st century, education should be geared towards the mastery of the 21st Century skills, which are curently called the 6Cs: Critical thinking, Collaboration, Communication,Creativity, Citizenship (or cultural awareness) and Connectivity (or Character education). The English lesson in secondary school is not an exception; it must also implement the 6 Cs in the teaching of the texts as decreed in the 2013 Curriculum. This paper has highlighted some ways that the skills of the $6 \mathrm{Cs}$ can be integrated into the English lessons. The activities are also tailored to embrace the PPK or the Strengthening of the Character Education as decreed by the President Joko Widodo in his eighth priority of the Nawa Cita (Nine Priorities) of the Indonesian Development.

Along with the implementation of the $6 \mathrm{Cs}$, teachers are also expected to apply the Higher Order Thinking Skills (HOTS) which are encouraged in the 2013 Curriculum and are closely related to the $6 \mathrm{Cs}$. In fostering the skills, teachers can refer to the Cognitive levels of Applying, Analyzing, Evaluating and Creating in Bloom's Taxonomy.

Finally, through the implementation of the $6 \mathrm{Cs}$, it can be expected that teachers and students can work well, hand-in-hand to build a better society, one that is ready to face the challenges of the 21st Century.

\section{References}

[1] Alismail, H.A. and McGuire, P. (2015). 21st Century Standards and Curriculum: Current Research and Practice. Journal of Education and Practice Vol.6 No.6 (www.iiste.org) retrieved on August 2, 2018 
[2] Fatimah, A.S., and Santiana. (2017) Teaching in the 21st Century: Student-Teachers' Perceptions of Technology Use in the Classroom. Script Journal (Journal of Linguistics and English Teaching), Vol.2, No.2, 2017

[3] Fullan,M. And Duckworth, S. (2015). 21st Century Skills: 6 Cs of Education.(www. blogawwapp.com) retrieved on July 15, 2018

[4] Hidi, S, and Harakiewicz, J.M. (2000). Motivating the Academically Unmotivated: A Critical Issue for the 21st Century. Review of Educational Research, Summer 2000, Vol.70, No.2, pp 151-179.

[5] Lombardi, M.M. (2007). Authentic Learning for the 21st Century: An Overview. Educause Learning Initiative (ELI Paper 1, May 2007)

[6] Maphosa, C. and Mashau, S. (2014). Examining the Ideal 21st Century Teacher Education Curriculum. International Journal of Educational Sciences Vol.7, 2014, Issue 2 (https://www.tandfonline.com/toc/reds20/current) retrieved on August 3, 2018

[7] Miller, B.S. (2015). The 6Cs Squared Version of Education in the 21st Century (www. bamradionetwork.com) retrieved on July 26, 2018 